\title{
Furnishing the salon: symbolic ethnicity and performative practices in Moroccan-Dutch domestic interiors
}

\author{
Hester Dibbits \\ Department of Ethnology, Meertens Institute, Royal Netherlands Academy of Arts and Sciences, Amsterdam, The Netherlands
}

\author{
Keywords \\ Material culture, migration, furniture, ethnicity, \\ Moroccans. \\ Correspondence \\ Hester Dibbits, Department of Ethnology, \\ Meertens Institute, Royal Netherlands \\ Academy of Arts and Sciences, PO BOX \\ 94264, NL-1090 GG Amsterdam, The \\ Netherlands. \\ E-mail: hester.dibbits@meertens.knaw.nl
}

doi: $10.1111 / j .1470-6431.2009 .00805 . x$

\begin{abstract}
Confronted with traditional-looking Moroccan furniture in a house where Moroccan migrants or their descendants live, one may interpret this furniture as an ethnic symbol, underlining the Moroccan, North African or Arabic background of the owners. Analysing interviews and discussions on the Internet, this article shows that the furniture has many other significances as well. It not only functions as an ethnic symbol, but also signals affluence and fashionability, and it appeals in different, often emotional ways to the senses of those who experience the furniture by sitting on it while eating, drinking and talking. Apparently the traditional-looking Moroccan furniture has the capacity to transport people to other worlds. For those who spent their childhood in Morocco, these are often worlds that are part of their embodied memory, while for those who grew up outside Morocco, these are more often worlds that are primarily imagined and appropriated through aesthetic images in glossy magazines and coffee-table books. In both cases however, traditionallooking Moroccan furniture appear to respond to an emotional longing for the (re-)creation of experiences of conviviality. Especially in interviews with first-generation Moroccan migrants, this emotional longing resonates more strongly than the wish to make a statement about ethnic belonging.
\end{abstract}

\section{Introduction}

Looking at the interiors of migrants and their descendants, one is often struck by the material references to the dwellers' countries of origin. These references can include small objects such as prints, wooden statues or musical instruments, but also whole sets of furniture either produced in the country of origin or in the country of residence (Metha and Belk, 1991; Joy et al., 1993; Miller, 1994; Ger and Østergaard, 1998; Roth, 1999; Kilickiran, 2003; Salih, 2003; Tolia-Kelly, 2004; Dibbits, 2005; Schwertl, 2008; Van der Horst, 2008).

There are various ways in which the presence of these objects can be analysed. One may consider them primarily as ethnic symbols, as artefacts referring to the ethnic identity of the dwellers; this is how authors following Gans (1979) would most likely interpret them, according to his seminal article 'Symbolic ethnicity: the future of ethnic groups and cultures in America'. In this article, Gans examined the way in which descendants of immigrants engage with the culture of their parents and grandparents. Gans' argument is that sooner or later the descendants of immigrants will distance themselves from what he calls 'the older ethnic culture', and express their ethnic ties only through the celebration of particular festivals and feasts, or through the acquisition of certain consumer goods. These festivals, feasts and consumer goods thus function as 'ethnic symbols', which are, according to Gans, 'visible and clear in meaning to large numbers of third generation ethnics, and they must be easily expressed and felt, without requiring undue interference in other aspects of life' (Gans, 1979, p. 9).

Instead of focusing on the symbolic meanings of artefacts, one can also look at their performative effects, their agency, their power and at the ways in which artefacts appeal to the sensorium. Questions about what artefacts do in different settings, how they matter, then become more important than questions about what they symbolize (see also Van der Horst, 2008): what is the effect of artefacts on people's individual behaviour and on social-cultural relations, what is their effect on people's emotions? In how far does the display in the domestic domain of artefacts affect both individual and social life?

As Bahloul has argued in her study on a Jewish-Muslim household in Colonial Algeria, artefacts may provide a material anchor to the remembrance of rituals or habitual practices that strengthen ties within a community. Remembering domestic space, objects and associated practices that have been transferred into the register of memory by repetitive use and have become symbolic representations of someone's habitus can be part of the rhetoric of nostalgia for a vanished community (Bahloul, 1996). In a study of Pakistani-British interiors, Tolia-Kelly has also pointed at the 
importance of visual and material cultures as constituting processes of identification, arguing that objects activate memories, which in their turn play a central role in discourses of heritage (Tolia-Kelly, 2004).

Van der Horst has taken an explicit performative approach in her study on the domestic interiors of Turkish and migrants and their descendants in the Netherlands. Focusing on the effects of artefacts within processes of socio-cultural positioning, she comprehends meaning as something created in time- and space-bound performative settings, and looks at what kind of socio-cultural positioning is performed within a setting where people interact with each other but also with their material surroundings. Through such interaction, in addition to meaning, also temporality, spatiality and human corporality take shape (Van der Horst, 2008).

Evidently, a focus on the performative effects of artefacts does not imply a farewell to the symbolic approach. Meanings are created in specific performative settings, but certain meanings can also become so dominant that they are inscribed in the artefacts themselves and consequently determine the setting. The inscribed symbolic meanings of artefacts deeply affect the ways in which they are experienced by people. Combining on this ground a symbolic and performative approach, I explore in this article the significance of so-called sedari for Moroccan migrants and their descendants living in the Netherlands. Sedari ${ }^{1}$ come in wideranging styles, but typically consist of low wooden frames with mattresses on them, running along three sides of the room. Both in Morocco and among Moroccan migrants and their descendants living abroad, sedari are very popular; both the traditionally decorated and the fashionably designed models.

The article is based on about 40 interviews. A significant share of these interviews was conducted by two master students. One of them was a Moroccan-Dutch male who interviewed in Arabic (his mother tongue) and therefore spoke mainly with Arabicspeaking Moroccan-Dutch, rather than people who spoke Berber or Dutch. The other master student was a female who grew up in the Netherlands, but whose father came from Scotland. We took photographs of the interviewees' interiors during most of the interviews. Next to interviews and photographs, the Internet was an important source of material. I read various forum discussions among Moroccans living abroad, related to 'Moroccan interiors' in general and the sedari in particular. Often, contributions to these Internet forums were accompanied by images scanned from coffee-table books or pictures of peoples' own sedari.

As all the interviews took place in the interviewees' apartments, there was ample opportunity to observe the actual use (or non-use) of the furniture in the interview settings. Although these observations have played an important role in the process of writing this article, I did not opt for a close reading of these settings. This article aims at a general exploration of the different significances of the furniture for Moroccan-Dutch migrants and their descendants, and not at an exploration of its significance in a specific setting.

However, it should be noted that especially in case of the interviews by the Scottish-Dutch master student and the author, the setting may have been coloured by a dynamic of strategic reïfication, as during these interviews on several moments, the inter-

${ }^{1}$ The spelling of the word sedari varies. The spelling used in this article can be found in many advertisements and other texts on the Internet. viewees will have experienced differences in ethnic, cultural and social background between him or herself and the interviewer (Baumann, 1996). The question in how far precisely this has coloured the findings, however, is not so easy to answer. After all, the awareness of being interviewed may result in some sort of strategic reification already, regardless of the background of the interviewer.

Obviously, there is no such a thing as 'the' Moroccan-Dutch community nor one Moroccan-Dutch identity. Counting more than 300000 persons, the Moroccan-Dutch are one of the four largest ethnic minority groups in the Netherlands, together with people of Turkish, Surinamese and Antillean descent. Most of them are former guest workers who came to the Netherlands in the 1960s and 1970s, or relatives of these guest workers. In public discussions about the social positioning of Moroccan-Dutch people in Dutch society, distinction is made alternately between Moroccan people having a rural background and those having an urban background, between Berbers and Arabs, or Arab-speaking Berbers, and between Moroccan-Dutch originating from the north and those who grew up in the south of Morocco. Berbers originating from rural parts in the north of Morocco are often considered as more 'traditional', but apparently orientations within this group are diverse, as they are also diverse in other groups (Bos and Fritschy, 2006). Still, as far as certain aspects of the furnishing of the domestic space are concerned, less diversity seems to exist. From the 40 Moroccan-Dutch interviewed between 2003 and 2005, more than 20 had sedari or intended to buy a set in the near future (Dickson, 2004; Dibbits, 2005).

When I first saw these sedari and heard about their popularity, I was inclined to consider them in a migration context primarily as ethnic symbols, as statements of Moroccanness. But this is not how Moroccan-Dutch usually talk about them. Only some of the interviewees reflected on their choice of furnishing in terms of ethnic symbolism. In most interviews, it was not the symbolic value of the sedari, but their practical qualities that people talked about most. A great concern for the suitability to everyday use and comfort in respect to the sedari appeared to exist. In this, an interesting and general difference can be noted between the interiors of Moroccan-Dutch and some other migrant groups in the Netherlands. While for example most vernacular Turkish objects found in Turkish-Dutch interiors were displayed in a way that stressed that they would never be used, most sedari were ready for actual use. Such general differences between migrant groups are significant and deserve more attention (Dibbits and Van der Horst, 2006, 2007). However, in this article I will focus on one migrant group and one piece of furniture, in order to do justice to the differences that exist within that group.

\section{The world of sedari}

Sedari are not a typical Moroccan phenomenon. From the Maghreb to Turkey and Iraq, one finds low banquettes running along three sides of the room, offering an alternative to the tradition of sitting on the floor on carpets or mattresses, and the tradition of sitting on fauteuils and couches. In their most simple form, sedari are just mattresses supported by a low wooden frame. Having no back, this frame is put directly against the wall. In most cases in Morocco, they appear in sets of three, together with a mida, a round or octagonal table. Sedari are further often 
accompanied by smaller round tables, poufs and chests for the storage of blankets. A dining table and chairs are unlikely to be found accompanying sedari: dinner is usually served on a large round copper tray that is placed on the mida. Compared with most European couches, the seats of sedari are rather low, and so are the tables on which dinner is served.

In the past decades, the market for sedari experienced a significant growth and as such the variation in models has become immense. Now there are for example several models with a back, being designed especially for European houses, where furniture cannot be put directly against the wall because of the presence of heating radiators and low windows. One of the biggest stores supplying Moroccan sedari is Richbond. This firm offers both traditional and contemporary models, the latter being displayed in a showroom together with figurative paintings and designer chairs. Alongside somewhat plain sedari that cost less than 200 euros per metre, Richbond also sells more expensive models for at least three times as much. Established in Casablanca in 1964, Richbond was one of the first firms supplying foam mattresses for sedari, offering an alternative to the traditional wool-filled mattresses, which were heavy and expensive. In 1995 Richbond expanded its business outside Morocco, anticipating, as a web site text said, 'the explosion in demand of Maghreb people living abroad, being nostalgic about everything which could bring into memory its origins, notably traditional furniture goods' (http://www. richbond.fr, accessed on 2 February 2006). The expansion turned out to be a success, and between 1995 and 2003, Richbond opened 11 stores abroad: five in France, one in Belgium, one in Canada, one in Switzerland and, in 2003, one in the Netherlands.

The sets sold by firms such as Richbond especially can be expensive, as they can cost up to 3000 euros or more. Moreover, one can be pushed towards further investments once one has actually bought sedari, particularly if one does not want to stay behind in fashion. Pointing at the sedari in her living room, one of our interviewees complained:

This is expensive; one has to renew the cloth as after 2 years it begins to look a bit old, you keep wanting to change it every time, and if guests come over, they will notice that you still have the same upholstery. And each time it will cost you 250-300 euros to have new upholstery made. A couch is easy, because you can cover it with a blanket, but this you also need to clean immediately after use, especially if my grandchildren come over.

One can read this excerpt as a simple complaint, but it also gives the investment extra weight: sedari are labelled as something that demands continuous financial investment, thus making the decision to buy one even more significant.

A willingness to invest a substantial sum of money in furnishing the dwelling in the country of residence has been noticed for various migrant groups. According to a research team that studied the interiors of Italian migrants in Montreal, the need for new, precious consumer goods is intensified by the uncertainties with which migrants are confronted (Joy et al., 1993). Kilickiran, who conducted research among Kurdish refugees in London, regards the investment in expensive furniture as a way in which migrants show that they are better off since they migrated (2003). And Heinze argues in his research on the consumer practices of Jewish migrants in the US around 1900 that the conspicuous display of consumer goods is a relatively easy way to display one's success as a citizen. A house full of new consumer goods compensates feelings of uncertainty about the future and validates a decision made in the past to migrate (Heinze, 1990; McMillan, 2003). What differ are the kinds of objects people surround themselves with: while most Jewish migrants in the US opted, for example, for the 'American' piano, Moroccan-Dutch choose 'Moroccan' benches. Moreover, many Moroccan-Dutch prefer to buy all the furniture for their Moroccan salon in Morocco, instead of in the Netherlands. Not only were differences in price and in supply mentioned as an explanation for this, but also the fact that artefacts made in one's (parents') home country have a specific emotional value. What is the same however for both groups is the investment and the care that people take in making a home in their country of residence.

\section{Two sitting areas, two separate worlds?}

Focusing on the appropriation of sedari in a migration context, we should pay at least some attention to the way sedari are integrated in general in the domestic space in Morocco, if only because this is an important frame of reference for Moroccan-Dutch people living in the Netherlands.

In Morocco up to the 1960s, sedari were found mainly among urban families, but during the last decades they have become a widespread piece of furniture, also among rural families. Now some people in Morocco regard them even as old fashioned and prefer a European lounge suite. But generally speaking, it is considered a natural thing to have at least one room furnished with sedari. The ideal seems to have both sedari and a lounge suite (Cammaert, 1985; Buitelaar, 2006; Eleb, 2006).

As in many other countries all over the world, it is common to have two sets of seating furniture because of the widely shared convention to furnish - if possible - two sitting rooms. As a rule, one of these sitting rooms is reserved for guests, or only for male guests if gender separation is desired. What varies is the type of furniture that is considered most appropriate for these two sitting rooms.

If there is one room available with sedari and one room with a European couch, it is often the latter, called salon roumi (from Roman, meaning foreign) or salon à l'Européenne, which functions as a guestroom, the lounge suite being experienced as a prestigious piece of furniture. The room with sedari [called bit la glass (salon de famille) or salon bildi (traditional salon)] is usually experienced as the more informal and intimate one. In larger houses, there is often a third sitting room, especially intended for festive occasions and a large number of guests, and this room as a rule is furnished with sedari. The reason to choose sedari here is often due to practical reasons, since sedari offer space for many people and the additional possibility to be used as a bed to sleep on.

Having said this, it should be noted that in Morocco sedari can also have a very representative outlook and function. There are many people who furnish their salon, either big or small, with expensive decorated benches and cover them with equally expensive cloth, and there are people - mainly higher educated ones with a European way of living - who do not have a separate guestroom, but who reserve in their 'European' living room a special corner for sedari. The reason for this is, according to the 


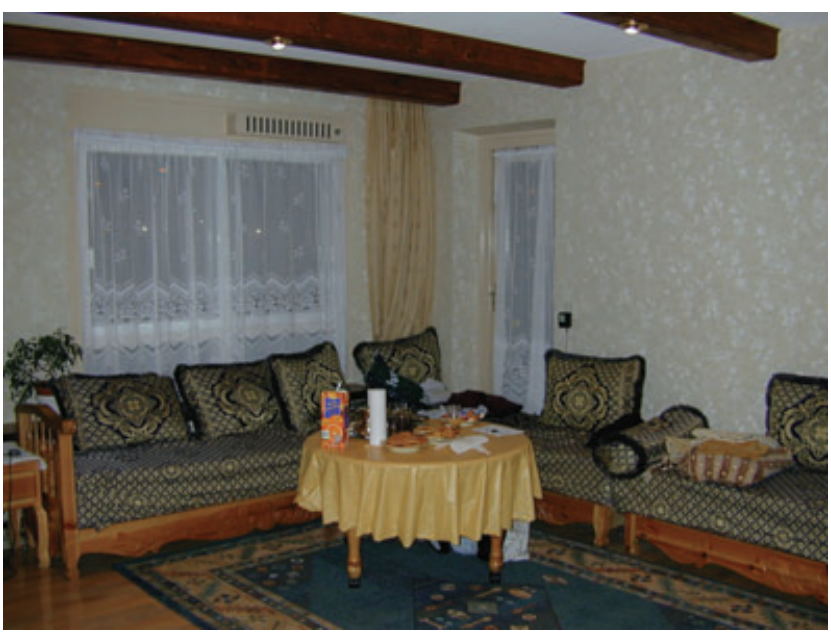

Figure 1 The living room in the house of Naima, Rotterdam, 2003 (photo: Shona Dickson).

ethnologist Monique Eleb who studied contemporary domestic practices in Casablanca, that they consider sedari as more convivial (Eleb, 2006).

In the Netherlands, it is different in that houses rarely have more than one living room. So most Moroccan-Dutch who buy sedari at least temporarily put them in their living room. In some cases, they replace the lounge or corner suite bought earlier, but it also happens that people keep their old couch and furnish two sitting corners in the one room: one with a lounge suite or corner seat, and one with sedari. Other households convert a bedroom or their garage into a sitting room, resulting in the presence of two living rooms. Apparently, the 'Moroccan' ideal to have two living rooms also exists among Moroccan-Dutch.

There were various reasons for why this was emphasized in the interviews. Some interviewees indicated that they wanted two sitting rooms because they liked the opportunity to keep one room tidy and ready for the reception of visitors. This was also why Naima (b. 1961), who came to the Netherlands when she was just married, 20 years ago, longed for an extra sitting room: 'If I had an extra room, I would have furnished it for us, and for the children, and I would have used the living room as a salon; that would be more practical, it would always be clean and tidy. Now this is not the case, it can happen that it is a mess when someone comes in, because this is the room where daily family life takes place' (Fig. 1).

Hafida (b. 1957), who also migrated to the Netherlands at the time of her wedding, had other reasons for dreaming about two sitting rooms. She finds it more comfortable when male and female guests can sit in separate rooms. When Hafida expressed a desire to have a wall constructed between the two sitting areas, her daughter warned her that this would be too expensive, and thus she proposed instead to buy shutters or hang a curtain between the two sitting corners, like several other first generation Moroccan-Dutch families appear to have done. For her mother, however, this would not be enough: 'The men would still hear us talking and chatting and laughing'.

Mohamed, another interviewee, a bit younger than Niama and Hafida, also preferred to have the opportunity to receive men and

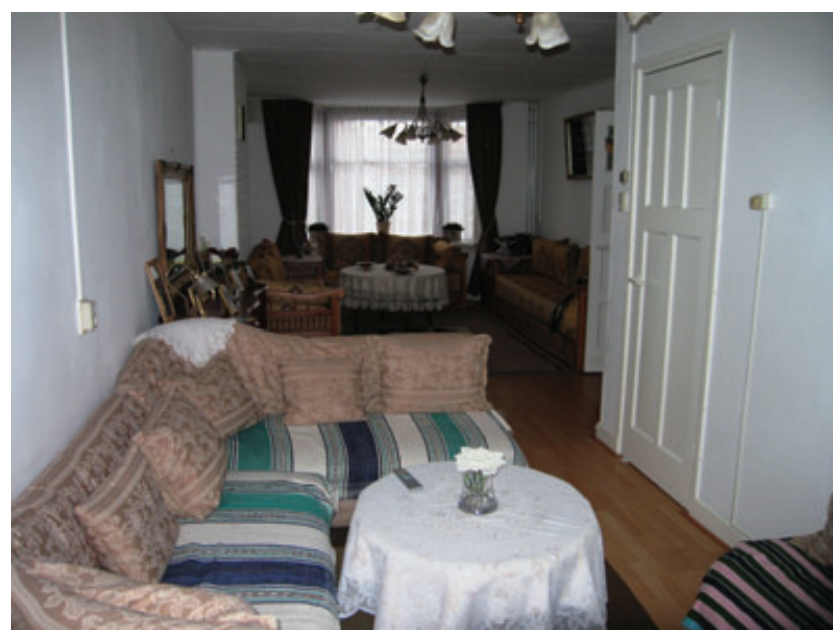

Figure 2 The living room in the house of Hafida, Amsterdam, 2007 (photo: Marijke van den Berg).

women in separate rooms. He explained that this was because he wanted to take the expectations of his guests into consideration: 'If there are plenty of guests, men and women should be able to sit in separate rooms; otherwise, nobody will come to your place.'

In the Netherlands the 'sedari room' is usually considered as the more special one: here the guests are received. Sedari are there to be shown to visitors, to be admired. In houses with both Morrocan sedari and a European lounge suite, often a distinction seems to be made between Moroccan and European accessories in such a way that the sitting areas are each other's counterparts. However, this apparent positioning of domestic furniture and accessories along neat categories often becomes blurred. Some small changes in Hafida's living room during my research are telling in this respect: the first time I visited her apartment, I had the impression there was a clear distinction between the Moroccan and the European corner, with incensories, a Koran stand, calligraphy and draped curtains in the sedari corner contrasting with a large TV, a picture of a lily and venetian blinds in the European one. But when I visited her for a second time, the distinction that I had noted on my first visit had become less obvious by the presence of the Berber cloth with which she had covered the European couch. If there had ever been the intention to use the interior for sustaining parallel identities or two different worlds, there was now little to be seen of such an intention. It made me realize how interiors may change from one moment to another, not necessarily because the dwellers want to make a different statement, but just because of practical or aesthetic reasons, or because of no reason whatsoever: the outlook of interiors simply changes from time to time (Fig. 2)

\section{Experiencing a familiar world}

Despite the last remarks above, it still seems reasonable to interpret the presence of sedari in a house where Moroccan-Dutch live as a result of a consciously made choice by the dwellers in order to underline their Moroccan, North African or Arabic background. The current popularity of sedari among Moroccan-Dutch may thus be analysed as an example of symbolic ethnicity, and 
sedari as ethnic symbols. One can think of various reasons why Moroccan-Dutch would consider it important to underline their Moroccan 'roots' by displaying artefacts - pieces of furniture included - that are easily recognized as typical Moroccan. One explanation could be that in contrast to the constant assertion of Moroccan-Dutch as 'foreigners', social space for performing Moroccan identity is not self-evident. Moroccan folklore may be celebrated by native Dutch, but at the same time Moroccan immigrants are urged to assimilate. While for some this situation brings them to downplay their Moroccan background, others - resisting the politics of assimilation - react in the opposite direction.

A few interviewees indeed explicitly said that they bought sedari, or intended to do so, to express their Moroccan origin. A social worker, born in 1968, explained why he intended to change his couch for sedari as soon as he had moved to another house: 'Outdoors, you are purely Dutch, indoors, you are Moroccan. Those manners and morals, one should acknowledge them'. For this informant, the sedari embody the Moroccan part of his identity. Nouredine, aged 39, a member of a rich family from Fez but who had left school at the age of 14 to work as a street seller in Fez, had a Moroccan salon furnished in his house in 2000, 3 years after he arrived in the Netherlands. His words imply more or less the same as those of the former interviewee, but his answer resonates more strongly an emotional longing: 'I like to feel my own culture. I feel that I have my own mansion inside Europe as a whole. It brings me some relaxation', he explained. Apparently, for this informant, sedari made him feel 'at home'.

Reading the interviews, it is these kinds of emotions that come to the fore very prominently. Apparently, the presence of the sedari evokes strong emotions among many people. Talking about the furnishing of a Moroccan salon, Naima said: '[. . . ] if you enter such a room, it is so beautiful, really, it gives you the feeling of being in my home country. Yes, it is first of all the feeling of being in Morocco'. Other interviewees gave similar answers. While we were both sitting on the sedari talking about the different corners, Hafida for example told me that she loved to walk from the one sitting corner to the other, from Morocco to the Netherlands. Apparently, for Nouredine, Naima and Hafida, as well as for other Moroccan-Dutch, the salon has the ability to transport them to Morocco, while being in the Netherlands.

For many of the interviewees, the main significance of sedari seems to be their capacity to remind people not so much of being Moroccan, but of being in Morocco: to bring back into memory their domestic life as experienced before they migrated to Europe, for example during their childhood.

Sedari evoke the kind of memories that were exchanged at Ztazen.com, an online community that aims at serving the Moroccan community living in the US. In 2005, a Moroccan-American explained at a chat site within this online community why he wants a salon furnished in a Moroccan style: '. . . the salon, at least should be Moroccan, the best moments in our life as children we spent in the salon' (http://ztazen.com, accessed on 5 August 2006).

By talking about sedari, by seeing sedari, but even more by sitting on them while eating, drinking and talking, a past can be evoked. Other objects can also evoke such a sensation, but the effect sedari have on everyday practices may make the remembrance even more intense. It is not only remembering, but also recreating the bodily postures. More in particular, the practice of sitting on sedari evokes 'bodily memories' not only of other homes, places and architectures, but more importantly of family time, and 'lost' sociabilities that can be recreated in the new country.

Against this background, it is not surprising that when talking about sedari, all interviewees pointed immediately at their functional qualities. They stressed the fact, for example, that in contrast with Western lounge suites, sedari offer seats for a relatively large number of people. Receiving a large number of people was mentioned by the interviewees over and over again as a typical 'Moroccan' practice. Naima indicated that she and her husband purchased sedari primarily for practical reasons: 'Honestly, initially I didn't even think of sedari. I still think a normal lounge suite is nice and lovely. But when one is receiving guests, one needs a chair and a stool, and that is inconvenient. Had we received less guests, I wouldn't have had these sedari.'

Sedari were also regarded as more suitable than most Western couches for napping during the day. And the fact that sedari can be used as sleeping couches for guests who stay for the night was mentioned as a positive thing for many of the interviewees, adding the explanation that in Morocco it is common for people to stay over for the night.

Entering a room furnished with sedari and Moroccan accessories apparently makes many Moroccan-Dutch feel 'at home', because it reminds them of pleasant moments back in Morocco. Could it even be that less pleasant memories of moments spent in a Moroccan salon improve at the sight of a nicely decorated set of furniture? Then such sedari do not just transport people to Morocco, but rather to a romanticized ideal of Morocco.

In the interviews, several factors were mentioned as preventing people from being carried away into another world. Daily life in the Netherlands is different from daily life in Morocco, and the sedari suggest a certain way of living that cannot automatically be effectuated. The siesta for example is not widely practised, and if one wants to take a nap during the day, one is expected to withdraw to a bedroom. And since travel time is short, guests typically travel back to their own homes and do not stay overnight. Above all, people experience a feeling of lack of time. On a French web site, someone called Zinc Negh wrote on 3 October 2005 (http:// www.yabiladi.com/forum/read-72-761380.html, accessed on 10 August 2007):

SEDARI!!!!! Don't be behind, friend, buy a couch at the IKEA store, sedari was fine at the time, for being able to offer comfort to guests who bursted in with 10 people, then, ok, one really needed sedaris along the 4 walls to have everybody seated around a table with atai [Moroccan green tea, author] and peanuts, but today nobody visits no one any more. People work and stay at home, the daily grind does not offer time any more, besides I don't like a salon that much. . . . . . For this writer, as for some of our interviewees, the familiarism suggested and celebrated through the purchase of sedari was not

${ }^{2}$ Full text in French: 'SEDARI!!!!!!! vis avec ton temps 1 ami, achete un canapé de chez ikea. sedari c etait bien dans le temps pour pouvoir offrire un confort aux invité qui deboulait en famille par 10, la ok il fallait bien des sedaris au longs des 4 murs pour contenir tous ces gens autour $\mathrm{d}$ une table berred $\mathrm{d}$ atai et des cacahuettes mais aujourd huit plus personne ne va chez plus personne. les gens travaillent et ce conditionnent chez eux, le train train de la vie aux quotidien $\mathrm{n}$ offre plus le temps. en plus je trouves ca moche dans un salon. ............. 
considered as something real, or at least not as something that a Moroccan salon would restore. It resembles the line of reasoning Bahloul found among her informants, and which brought her to conclude that familiarism is comfortable as long as it does not interfere with the individual's attempts at social advancement and integration into local society [Bahloul, (1992) 1996, p. 31].

Not all found the sedari pleasant or practical. Some indicated that sedari just did not go with their way of living. One interviewee explained that she removed the sedari because she lived on her own and rarely received guests. Others indicated that they could not get adjusted to the material characteristics of sedari. One female informant, born in 1975 in Morocco but raised in the Netherlands, pointed at the specific qualities of sedari with regard to habitual ways of sitting. Offering insight into how difficult it is to adjust ones' habitus [Bourdieu, (1979) 1984; Roodenburg, 2004], she told us that she found sedari very uncomfortable to sit on: 'They make you to sit in a stiff way', she explained. Apparently sitting on sedari was not part of her 'bodily memory' (Connerton, 1989), because she was used to sitting on a soft European-style couch. With her sitting habit being so different, she decided to replace the sedari for something she was more familiar with. She did try to adjust her habitual sitting practices, but after a while she decided to remove the sedari from her living room and revert to a couch. For this informant, the sedari is hardly used at all, and in the long run functions only as a piece of display furniture, without an everyday use (see also Van der Horst, 2008).

There were also interviewees who did not like the idea of having sedari, or a Moroccan salon at all. A student aged 33, said for example: 'A Moroccan salon will not add something special to the house. If miss it I would go to Morocco. On the other hand, I will buy a small Berber carpet, some handmade products like calligraphies, pictures showing Moroccan nature or Moroccan culture. In general I feel at ease using the Dutch sofa.' Apparently, he did like to have some Moroccan objects in his house, but only for display and not for use. Others told the interviewers that they did not need to have any Moroccan objects around them to feel at home; because they had an emotional tie to Morocco, Morocco was always in their minds. Reflections such as these show how the need for visualizing, materializing or experiencing imagined settings differs from one person to another, just as it may differ according to one's phase of life. Against this background, the popularity of sedari among Moroccan-Dutch may seem even more surprising. However, as I will show in the next paragraph, furnishing a Moroccan salon may have significance not only for re-creating the past, but also for facilitating various other sorts of experiences.

\section{Experiencing an exotic world}

As already established, sedari appear to evoke positive memories of daily life in Morocco as experienced during one's youth or during holidays and thus help construct an idealized Moroccan world. Sedari may also evoke images of an Oriental world as it is constructed in the advertisements of firms such as Richbond, in pictures in glossy magazines, in films and in television series, a world that represents and shapes aestheticized images of the Orient, inspired by 18th- and 19th-century traditions of exoticism and Orientalism. These images are not only part of the visual archives of many Europeans, but also of other people, MoroccanDutch included.
Maryam, for example, aged 28 and born in the Netherlands, dreams about sedari in a cosmopolitan style. In her apartment, where she lives with her husband and two small children, no sedari can be found. But she does have various objects and she intends to purchase sedari one day. To illustrate what she had in mind, she e-mailed me several pictures after our interview. They appeared to be exactly the same sort of pictures that can be found in glossy magazines, in coffee-table books, and on Internet fora for Moroccan migrants such as http://marocoase.kostenloses-forum.tk (accessed 12 October 2006): dream interiors of a 'Moroccan style', which apparently appeals to (aspirant) middle-class people all over the world (see also Salih, 2003, p. 60).

When reading some of the conversations about interior decoration on the Internet, one gets the impression that some Moroccan-Dutch youngsters consciously play with the widely shared popularity of Oriental material culture and appeal to this with their 'Moroccan interior'. A conversation on the Dutch web forum Marokko Community nicely illustrates this. First, one of the members writes:

[I]nschallah in my new house I will have a room upstairs decorated in a Moroccan style, and the living room will be just in western style. This is much nicer, and in this way you have two combinations, and also if family comes over, at least my family, men and women are seated apart from each other. Someone else answered a couple of minutes later: 'Come on ladies, we live in the Netherlands, and in my opinion this means that we should have a western interior style!' Another member then reacts saying:

Yes, my living room is also furnished in western style. But a second room, which is not used by us, I would like to furnish in Moroccan style. I do this especially for Dutch guests, because they are really fond of it!!! Also, it would perfectly match eating couscous; $)^{3}$

The last quote, closing with a wink of the eye, shows a reflection one seldom comes across in the interviews. The writer plays with the fashionable image of the Moroccan interior. Presumably Dutch guests are not the main reason for furnishing a salon, and maybe the whole remark is meant as a joke, but the author of this message also shows a consciousness of the influence of the Dutch context on the furnishing of her house. This influence does not stand on its own, but is part and parcel of a general process of incorporation of essentialized ideas of Morocco by Moroccans in Morocco as well as people of Moroccan descent living abroad.The Orientalist image of Morocco is based on several elements, on interior and

${ }^{3}$ http://forums.marokko.nl/archive/index.php/t-655313-p-2.html, accessed 07/08/07.

Full text in Dutch:

Achtermijnpc: '[I]nschallah bij mijn nieuwe huis ga ik 1 kamer boven zo decoreren in het marokkaans en de woonkamer word gewoon westers. [Dat] is veel mooier en zo heb je 2 combinaties, en ook als er familie komt, tenminste die van mij, dan zitten de mannen en de vrouwen alleen'.

Touri Touri: 'Nou dames, we wonen in Neder[1]and dus dan vind ik dat we ook een westerse huisstijl moeten hebben! [...]'.

Smurfi: 14:51 'ja, mijn huiskamer is ook westers ingericht. Maar een 2e kamer die bij ons vrijstaat wil ik marokkaans inrichten. En dat voornamelijk voor Nederlandse visiete. Die vinden het namelijk helemaal geweldig!!! Dat zou de marokkaanse/oosterse sfeer namelijk net rond maken bij het eten van couscous; ') 
housing traditions, but also on traditions in food and clothing. A female informant, who came to the Netherlands at the age of 20 after having studied Arabic at the university in Morocco for a year, told us that she and her husband intended to buy sedari in the near future. It was her husband who persuaded her in this by taking her along to the Richbond showrooms. Once sedari were installed in her home, she would receive her guests 'in style': 'Yeah, just in a real Moroccan way, and then I will also make Moroccan things, like tea, and I will speak Arabic'. The only problem was that she first needed to move to a bigger house, because she wanted to furnish a special room for this - as we may call it - performance of 'Moroccanness'. Furnishing a Moroccan salon and actually using it for the reception of guests implies practices that this informant may have experienced as rather habitual, because she grew up in Morocco. But just as for other Moroccan immigrants and their descendants, these practices are not any longer selfevident, because the Dutch context is different from that in Morocco.

For many Moroccan-Dutch, practices such as drinking Moroccan tea, and eating couscous in a Moroccan salon are not selfevident, or habitual practices. In those cases, the performance or re-invention of such practices may become either symbolic ethnicity in action, or simply something else, namely a performance of an imagined 'Oriental world'. Being practices that were not bodily memorized as daily routines, but only visually memorized through images, these practices may become, in other words, 'performances of belonging' or 'performances of longing'. For these Moroccan-Dutch, sitting on sedari in a Moroccan salon is not part of a routinized habitus, but a ritual, cultivated as something that is considered to belong in a natural way to Moroccan people living all over the world, or to the fashionable aesthetic world as constructed in coffee-table books. Not only native Dutch may experience these practices as such, but also Moroccan-Dutch, especially those Moroccan-Dutch who have least internalized these practices, those who feel that these practices are becoming less prominent parts of their (bodily) memory or those who are confronted daily with alternative habitual practices, either in the domestic or in the public sphere.

\section{Conclusion}

Artefacts, Moroccan furniture included, have multiple and divergent meanings. They may signal affluence and they may underline the background of the dwellers, they may function as signs telling 'others' what kind of people are living in a house. From the interviews, however, one gets the impression that for our interviewees, it is first of all their capacity to transport people to other places that is important.

Among those Moroccan-Dutch who were born in Morocco and lived in Morocco for several years, sedari evoke memories of daily (family) life in Morocco, even if the quality of sedari is totally different from the quality of the benches that were actually used in Morocco. Moreover, it is not only sedari themselves that transport them to Morocco. The related bodily practices are as important as the sedari; these were memorized, appropriated as part of their habitus and recalled when sitting on the benches. For others, especially younger Moroccan-Dutch, sedari may transport them to an imagined world that is part of their visual archive, in which visual images of Morocco, or the Orient, are stored.
Once Morocco (or the Orient) is no longer only displayed, but also experienced, by sitting in a Moroccan salon, the furniture becomes part and parcel of a concrete social performance that may constitute new social networks. Through practices related to the sedari, such as drinking tea, eating couscous, sitting, sleeping, watching television and having dinner with relatives or friends, social networks are constructed and reconstructed. While continuously reinventing, adjusting and reshaping these practices however, they can also be easily appropriated in an essentialized way as Moroccan, as belonging to Moroccan culture.

As we noted in the introduction to this article, many migrants and their descendants surround themselves with objects that refer to their country of origin. Apparently, migration causes at certain moments a longing for some familiar things, either immaterial or material; things that trigger the senses and evoke memories of the country of origin. The widely shared interest among descendants of Moroccan migrants for traditional-looking artefacts from their parent's home country is not something particular. All over the world, people re-create imagined distant worlds. And thus, while some opt for a small picture on the wall or a display of souvenirs in a glazed cabinet, others furnish their house with fashionable, but simultaneously traditional-looking Moroccan benches and invite family or friends to join them eating Moroccan food and drinking Moroccan tea.

Maybe it is not that people's dreams are so different. What differs, are the ways in which their dreams are visualized, materialized, performed and consequently embodied. That these performative displays and domestic rituals may also function as ethnic symbols, and possibly are intended by the dwellers to function as such as well, is not unlikely in a world where the construction of ethnic boundaries seems to be have become a normal thing to do. But when analysing material and consumer cultures of migrants and their descendants, it is important not to forget peoples' love for travelling to the places of their imagination.

\section{References}

Bahloul, J. [1992 (1996)] The Architecture of Memory. A Jewish-Muslim Household in Colonial Algeria, 1937-1962. Cambridge University Press, Cambridge.

Baumann, G. (1996) Contesting Culture: Discourses of Identity in Multi-Ethnic London. Cambridge University Press, Cambridge.

Bos, P. \& Fritschy, W. (eds) (2006) Morocco and the Netherlands. Society, Economy, Culture. Vu University Press, Amsterdam.

Bourdieu, P. [1979 (1984)] Distinction, a Social Critique of the Judgement of Taste. Routledge, London.

Buitelaar, M. (2006) Islam en het dagelijks leven. Atlas, Amsterdam/ Antwerpen.

Cammaert, M.-F. (1985) Migranten en thuisblijvers: een confrontatie. De leefwereld van Marokkaanse Berbervrouwen. Universitaire Pers, Leuven.

Connerton, P. (1989) How Societies Remember. Cambridge University Press, Cambridge.

Dibbits, H. (2005) Nieuw maar vertrouwd. Migranteninterieurs, sociale klasse en etniciteit. Sociologie, 1, 143-159.

Dibbits, H. \& Van der Horst, H. (2006) Turkish-Dutch, Moroccan-Dutch and the guest room. Paper presented at the ESA conference, Gent, 17 November 2006.

Dibbits, H. \& Van der Horst, H. (2007) Turkse en Marokkaanse Nederlanders Thuis. Amsterdam University Press, Amsterdam. 
Dickson, S. (2004) De Migrantenwoning: van huis naar thuis. Een historisch onderzoek naar de ontwikkeling van de huiselijke materiële cultuur van Marokkaanse migranten in Nederland, 1960-2003. Graduate thesis. Erasmus University Rotterdam.

Eleb, M. (2006) L'évolution de l'habitat et des modes de vie à Casablanca. In Morocco and the Netherlands. Society, Economy, Culture (ed. by P. Bos \& W. Fritschy), pp. 226-236. Vu University Press, Amsterdam.

Gans, H.J. (1979) Symbolic ethnicity: the future of ethnic groups and cultures in America. Ethnic and Racial Studies, 2, 1-20.

Ger, G. \& Østergaard, P. (1998) Constructing immigrant identities in consumption: appearance among the Turko-Danes. Advances in Consumer Research, 25, 48-52.

Heinze, A.R. (1990) Adapting to Abundance. Jewish Immigrants, Mass Consumption, and the Search for American Identity. Columbia University Press, New York.

Joy, A., Hui, M., Kim, C. \& Laroche, M. (1993) The cultural past in the present: the meaning of home and objects in the homes of workingclass Italian immigrants in Montreal. In Marketing in a Multicultural World: Ethnicity, Nationalism, and Cultural Identity (ed. by J.A. Costa \& G.J. Bamossy), pp. 145-179. Sage Publications, London. Kilickiran, D. (2003) Féminisme et sens de l'espace domestique des femmes déplacées. Les réfugiées Kurdes à Londres dans leurs appartements. In Espaces Domestiques: Construire, Habiter, Représenter (ed. by B. Colligingon \& J.F. Staszak), pp. 354-396. Bréal, Rosny-sous-bois.
McMillan, M. (2003) The 'West-Indian' front room in the African diaspora. Fashion Theory, 7, 397-413.

Metha, R. \& Belk, R.W. (1991) Artifacts, identity, and transition: favorite possessions of Indians and Indian immigrants to the United States. Journal of Consumer Research, 17, 398-411.

Miller, D. (1994) Modernity. An Ethnographic Approach. Dualism and Mass Consumption in Trinidad. Berg Publishers, Oxford.

Roodenburg, H. (2004) Pierre Bourdieu. Issues of embodiment and authenticity. Etnofoor, XVII, 215-226.

Roth, K. (1999) Zur Sache! Materielle Kultur und interkulturelle Kommunikation. In Netzwerk Volkskunde. Ideen und Wege (ed. by F. Grieshofer), pp. 317-335. Verein für Volkskunde, Wenen.

Salih, R. (2003) Gender in Transnationalism. Home, Longing and Belonging among Moroccan Migrant Women. Routledge, London and New York.

Schwertl, M. (2008) Living transnational room in the living room: Vom transnationalen Habitus in deutsch-/türkischen Wohnungen. Schweizerisches Archiv für Volkskunde, 104, 197-213.

Tolia-Kelly, D.P. (2004) Processes of identification: precipitates of re-memory in the South Asian home. Transactions of the Institute of British Geographers, 29, 314-329.

Van der Horst, H.J. (2008) Materiality of belonging. The domestic interiors of Turkish migrants and their descendants in the Netherlands. PhD Dissertation, Meertens Institute (KNAW), University of Amsterdam. 